\title{
Change in Land Use and Cropping Pattern in Assam: An Economic Analysis
}

\author{
N. Deka, J.P. Hazarika, P.P. Bora and R. Buragohain* \\ Department of Agricultural Economics, Assam Agricultural University, Assam, India \\ *Corresponding author: bgohain5rinu@gmail.com
}

\begin{abstract}
The economy of Assam is predominantly agrarian in nature having 28.11 lakh hectares of net cultivated area. In the study, Location coefficient (L), Simpson Diversity Index and CGR were used as analytical tools. In the state, net area sown, total cropped area and area sown more than once had increased. On the other hand, significant negative growth was recorded for forest area, barren and unculturable land, permanent pastures and other grazing land, land under miscellaneous trees, groves and fellow land. Higher concentrations of forest area, area sown more than once and lands put to non-agricultural purposes were reported in the state. Rice is the major crop in Assam accounting 60.87 per cent of the total cropped area during 2015-16. North Bank Plain Zone, Upper Brahmaputra Valley Zone and Hill Zone were reported to have higher crop diversification whereas, Central Brahmaputra Valley Zone, Lower Brahmaputra Valley Zone and Barak Valley Zone showed lower crop diversification.
\end{abstract}

Keywords: Land use, cropping pattern, Location coefficient, CGR, Simpson Diversity Index

Assam is one of the easternmost states of Indian union with a geographical area of 78438 sq. km, (of this 20\% hilly) which is about 2.4 per cent of the country's total geographical area providing shelter to country's 2.6 per cent population. An analysis of sectoral contribution to GSDP at constant (2011-12) prices from 2011-12 to 2015-16 indicate that the contribution of Agriculture and allied activities is expected to marginally decrease from the level of 19.89 per cent in 2011-12 to 18.66 per cent level in 2015-16 (Economic survey of Assam, 2016-17). The economy of the state is predominantly agrarian in nature. The net cultivated area of the state is 28.27 lakh hectares (2014-15), which is about 88 per cent of the total land available for agricultural cultivation. Rice being the staple crop occupies 87.89 per cent of the net cropped area and 60.87 per cent of the gross cropped area in 2015-16 (Economics Survey of Assam, 2016-17). The state has its climatic and physiographic features favourable for rice cultivation and the crop is grown in a wide range of agro-ecological situations. Rice is grown mainly in three seasons and they are named as Sali rice (winter rice), Ahu rice (autumn rice) and Boro Rice (summer rice). Another type Bao rice (deep water rice) is grown in some pockets of the state. There exists yield gap between farmers' field and experimental plots due to various reasons such as vagaries of monsoon with weather aberrations, frequent flooding and water inundation in plains periodic droughts in between showers in critical growth stages, high incidence of insect pest due to high humidity, non adherence of recommended package and practices, inadequate availability of quality seeds, low light intensity during the Kharif season, lack of awareness about the new varieties/ technologies etc. (http://www.rkmp.co.in). Of late, some of the cropped area is shifted for some other purpose such as for dwelling house and industrial uses. Land put to non-agricultural uses are increasing alarmingly leaving less area for crop cultivation. It was felt necessary to examine the land use scenario in the state and hence the present study aims to explore the existing land use and cropping pattern in Assam. 


\section{Methodology}

The study used secondary data collected from various sources on land use and cropping pattern in Assam. Simple analyses as stated below were used to analyse the land use and cropping pattern. The data considered were from 1990- 91 to 2015-16.

\section{Compound growth rate}

The exponential functional form:

$$
\begin{aligned}
& Y=a b^{t} \\
& \text { Or, } \ln y=\ln a+t \ln b
\end{aligned}
$$

Where,

$$
\begin{aligned}
& y=\text { time series data on input, output and TFP } \\
& b=\text { regression coefficient } \\
& t=\text { time period in years }
\end{aligned}
$$

Compound Growth Rate (CGR) was computed by using the formula:

$$
\text { CGR }(r)=(\text { Antilog } b-1) \times 100
$$

To estimate the contribution of TFP in agriculture, its per cent share in total output was estimated.

To test the significance level of CGR the following formula was used:

$\mathrm{SE}(\mathrm{r})=\sqrt[100 b]{\frac{1}{\left(\log _{10} e\right)^{2}}} \frac{\Sigma \log y^{2}-\Sigma(\log y)^{2}-\left(\log _{10} b\right)^{2} \Sigma x^{2}}{(n-2) \Sigma x^{2}}$

\section{Location Coefficient}

Location coefficient (L) is useful to identify the pattern of distribution of the given category of lands across different regions of a country or state. This is defined as follows:

$$
\begin{array}{ll}
L_{i j} & L_{i} \\
\hline L_{j} & L_{s}
\end{array}
$$

Where,

$\mathrm{L}_{\mathrm{ij}}=$ area of $\mathrm{j}^{\text {th }}$ category of land in the state

$\mathrm{L}_{\mathrm{i}}=$ area of all categories of land in the state

$\mathrm{L}_{\mathrm{j}}=$ area of $\mathrm{j}^{\text {th }}$ category of land in the Country

$\mathrm{L}_{\mathrm{s}}=$ area of all categories of land in the Country

A higher value for location coefficient for a state indicates the higher concentration of that particular category of land in that state.

\section{Cropping Diversification}

In the given study, Simpson Diversity Index was used to measure the extent of diversity and was calculated as follows:

$$
\mathrm{DI}=1-\Sigma \mathrm{P}_{\mathrm{i}}^{2}
$$

Where,

$\mathrm{P}_{\mathrm{i}}=$ Proportionate area of the $\mathrm{i}^{\text {th }}$ crop in the Gross Cropped Area

$\mathrm{i}=1,2,3 \ldots . \mathrm{n}$ is the number of crops

The index ranges between 0 and 1 . If there is specialisation then the index moves towards zero. In other words for $\sum \mathrm{P}_{i}^{2}=1$ there will be complete specialization (Bhattacharyya, 2008).

\section{RESULTS AND DISCUSSION}

\section{Land use Pattern of Assam}

The rapid pace of economic development along with population growth, urbanization and industrialization exert tremendous pressure on the limited natural resource base of a country. Land, being one of the most basic natural resource has always been the subject matter debate regarding its effective use. The changes in proportion of different categories of lands in Assam presented in Table 1 reveal that during 2003 to 2015, there had been increase in the net area sown, total cropped area and area sown more than once. However land put to non-Agricultural uses, cultivable wastes, permanent pastures and lands under tree crops and groves and fallow land other current fallow also exhibited positive growth. Whereas, forest area, barren \& un-cultivable land and current fellow land showed declining trend. A significant negative growth in forest area $(-0.59 \%)$, barren and unculturable land $(-1.86 \%)$, current fellow $(-4.66 \%)$ was observed. On the other hand, significant positive growth in land put to non-agricultural uses by 2.09 per cent, permanent pastures by 0.52 per cent, lands under tree crops and groves by 0.49 per cent (nonsignificant), culturable waste land by 6.14 per cent, fallow land other current fallow by 3.11 per cent, net area sown by 0.29 per cent, total cropped area by 0.63 per cent and area sown more than once by 1.45 per cent were recorded. The increase in net area sown and total cropped area is due to more area 
Table 1: Land use pattern of Assam (in thousand ha)

\begin{tabular}{|c|c|c|c|c|c|}
\hline Particulars & TE 1993 & TE 2003 & TE 2012 & TE 2015 & CGR (\%) (2003-15) \\
\hline Geographical Area & 7843.80 & 7843.80 & 7843.80 & 7843.80 & 0.00 \\
\hline Forest & 1984.18 & 1932.72 & 1853.26 & 1853.51 & $-0.59^{* *}$ \\
\hline \multicolumn{6}{|c|}{ Not available for cultivation } \\
\hline Land put to non-Agricultural uses & 946.88 & 1080.20 & 1152.03 & 1268.92 & $2.09^{* *}$ \\
\hline Barren and Unculturable Land & 1514.15 & 1452.75 & 1408.15 & 1192.93 & $-1.86^{* * *}$ \\
\hline Total & 987.70 & 2532.95 & 2560.19 & 2461.85 & -0.04 \\
\hline \multicolumn{6}{|c|}{ Other Unculturable Land excluding fallow Land } \\
\hline Permanent Pastures and other Grazing Land & 177.02 & 159.97 & 159.87 & 169.51 & $0.52^{*}$ \\
\hline $\begin{array}{l}\text { Land under Misc. trees, groves etc. (Not } \\
\text { included in Net Area) }\end{array}$ & 237.98 & 208.66 & 195.84 & 223.00 & 0.49 \\
\hline Culturable Waste land & 98.93 & 76.54 & 77.10 & 143.77 & $6.14^{* *}$ \\
\hline Total & 513.92 & 445.17 & 432.81 & 536.28 & $1.70^{*}$ \\
\hline \multicolumn{6}{|c|}{ Fallow Land } \\
\hline Fallow Land other than current fallow & 79.31 & 64.99 & 50.25 & 86.28 & $3.11^{*}$ \\
\hline Current Fallow & 82.60 & 100.61 & 79.25 & 87.43 & $-4.66^{* *}$ \\
\hline Total & 161.91 & 165.59 & 129.50 & 173.71 & -1.62 \\
\hline Net Area sown & 2729.78 & 2773.58 & 2810.60 & 2818.45 & $0.29^{* * *}$ \\
\hline Total Cropped Area & 3795.49 & 4012.03 & 4146.36 & 4086.01 & $0.63^{*}$ \\
\hline Area sown more than once & 814.69 & 1237.56 & 1335.74 & 1267.56 & $1.45^{*}$ \\
\hline Cropping Intensity & 139.02 & 144.65 & 147.53 & 144.97 & $0.35^{*}$ \\
\hline
\end{tabular}

* Significant at 10\%, ${ }^{* *}$ significant at 5\%, ${ }^{* * *}$ significant at $1 \%$ significance level; Source: Directorate of Economic and Statistics, Govt. of Assam.

brought from current fallow land for growing more crops. Similar result of increase in net area sown has been reported in Karnataka by Premakumara and Seema (2013). However, Mohanty (2007) reported decline in the net area sown, which was mainly attributed to increasing conversion agricultural land into non-agricultural purpose. In a dynamic world, certain modification can occur in the existing pattern of land utilization (Lekhi and Singh, 2011). Cropping intensity had slightly improved by 0.35 per cent in 2015 when compared to 2003.

The location coefficients were estimated to study the dynamics of different categories of land in the state. The results from the analysis provided in Table 2 indicate that the highest concentration of land was found in Assam for land under Misc. trees, groves (2.97), followed by barren and unculturable Land (2.93) and land put to non-agricultural uses (1.98). Forest area, area sown more than once, total cropped area and net area sown were also reported to have higher concentration in the state when compared to national level accounting the value of $1.08,0.90,0.86$ and 0.85 , respectively.

\section{Cropping pattern in Assam}

Rice is the major crop in Assam accounting 60.87 per cent of the total cropped area during 2015-16. Total rice covered 24.95 lakh hectares in the state in TE 2016. Individually, winter rice occupied the highest area (18.84 lakh ha) followed by summer rice (4.07 ha) in the cropping pattern of the state in TE 2016. Total cereals including rice, wheat and maize, occupied 74.50 per cent of total cropped area in the state. For TE 2015-16, total cereal occupied 25.52 lakh ha of land. Total pulse accounted 3.59 per cent by occupying 1.47 lakh ha during TE 2015-16. Area under total food grain was 26.99 lakh ha during the same period. Again, total oil seed accounted 7.62 per cent of total cropped area covering 3.04 lakh ha.

\section{Extent of crop diversification in Assam}

Crop diversification indices (CDI) of all the six zones and of the state as a whole were estimated for the years of 2005-06 and 2015-16 (Table 4). During the both years, the highest CDI was observed in LBVZ and the lowest CDI was observed in UBVZ. 
Table 2: Dynamics of distribution of different categories of land in Assam, 2014-15

\begin{tabular}{cccc}
\hline Particulars & Assam ('000 ha) & India ('000 ha) & Location Coefficient \\
\hline Geographical area & 7844 & 328726 & - \\
Forest & 1853 & 71794 & 1.08 \\
Land put to non-Agricultural uses & 1271 & 26883 & 1.98 \\
Barren and Unculturable Land & 1190 & 16996 & 2.93 \\
Permanent Pastures and other Grazing Land & 167 & 10258 & 0.68 \\
Land under Misc. trees, groves etc. (Not & & 3104 & 2.97 \\
included in Net Area) & 220 & 12469 & 0.48 \\
Culturable Waste land & 142 & 11092 & 0.33 \\
Fallow Land other than current fallow & 87 & 15091 & 0.24 \\
Current Fallow & 87 & 140130 & 0.85 \\
Net Area sown & 2827 & 198360 & 0.86 \\
Total Cropped Area & 4083 & 58230 & 0.90 \\
Area sown more than once & 1255 & & \\
\hline
\end{tabular}

Table 3: Cropping pattern in Assam from 1973 to 2016 (area in lakh ha)

\begin{tabular}{ccccccc}
\hline Crops & TE 1973 & TE 1983 & TE 1993 & TE 2003 & TE 2013 & TE 2016 \\
\hline Autumn rice & $5.34(22.49)$ & $5.96(21.37)$ & $6.26(19.74)$ & $5(15.89)$ & $2.76(8.92)$ & $2.04(6.61)$ \\
Winter rice & $14.24(59.98)$ & $16.31(58.48)$ & $17.94(56.56)$ & $17.47(55.51)$ & $18.64(60.27)$ & $18.84(61.05)$ \\
Summer rice & $0.32(1.35)$ & $0.35(1.25)$ & $1.31(4.13)$ & $3.27(10.39)$ & $3.95(12.77)$ & $4.07(13.19)$ \\
Jute & $1.3(5.48)$ & $1.1(3.94)$ & $0.97(3.06)$ & $0.69(2.19)$ & $0.64(2.07)$ & $0.71(2.30)$ \\
Rapeseed \& mustard & $1.41(5.94)$ & $2.29(8.21)$ & $2.96(9.33)$ & $2.69(8.55)$ & $2.57(8.31)$ & $2.82(9.14)$ \\
Potato & $0.26(1.10)$ & $0.4(1.43)$ & $0.62(1.95)$ & $0.79(2.51)$ & $0.93(3.01)$ & $1.02(3.31)$ \\
Wheat & $0.53(2.23)$ & $0.99(3.55)$ & $0.78(2.46)$ & $0.7(2.22)$ & $0.4(1.29)$ & $0.25(0.81)$ \\
Black gram & NA & NA & $0.32(1.01)$ & $0.4(1.27)$ & $0.5(1.62)$ & $0.53(1.72)$ \\
Sugarcane & $0.34(1.43)$ & $0.49(1.76)$ & $0.38(1.20)$ & $0.26(0.83)$ & $0.29(0.94)$ & $0.29(0.94)$ \\
Masur & NA & NA & $0.18(0.57)$ & $0.2(0.64)$ & $0.25(0.81)$ & $0.29(0.94)$ \\
Total cereals & 20.66 & 23.98 & 26.57 & 26.74 & 26.01 & 25.52 \\
Total pulses & 0.91 & 1.18 & 1.13 & 1.25 & 1.33 & 1.47 \\
Total food grains & 21.56 & 25.16 & 27.68 & 27.64 & 27.23 & 26.99 \\
Total oilseed & 1.56 & 2.49 & 3.21 & 3.38 & 2.79 & 3.04 \\
\hline
\end{tabular}

Source: Directorate of Economics and Statistics, Assam; Figure in parentheses indicates the per cent share to total crop area under those ten crops

The table revealed that in LBVZ, CBVZ and NBPZ more diversified crops were grown where as UBVZ and BVZ were characterized by mono-cropping especially with rice. Hill zone was found to exhibit moderate diversification of crops.

From Table 4, it is observed that except UBVZ and $\mathrm{HZ}$, all other four zones experienced a declined crop diversification in 2015-16 over 2005-06. As a result, the whole state experienced a slight decline in crop diversification from 0.61 in $2005-06$ to 0.59 in 2015-16.
Table 4: Zone wise Crop diversification in Assam

\begin{tabular}{ccc}
\hline Zones & 2005-06 & 2015-16 \\
\hline $\begin{array}{c}\text { North Bank Plain Zone (NBPZ) } \\
\text { Upper Brahmaputra Valley Zone } \\
\text { (UBVZ) }\end{array}$ & 0.64 & 0.61 \\
$\begin{array}{c}\text { Central Brahmaputra Valley Zone } \\
\text { (CBVZ) }\end{array}$ & 0.25 & 0.28 \\
$\begin{array}{c}\text { Lower Brahmaputra Valley Zone } \\
\text { (LBVZ) }\end{array}$ & 0.68 & 0.64 \\
Barak Valley Zone (BVZ) & 0.35 & 0.71 \\
Hill Zone (HZ) & 0.46 & 0.50 \\
Assam & 0.61 & 0.59 \\
\hline
\end{tabular}




\section{CONCLUSION}

The study concluded that there was positive growth in land put to non-Agricultural uses, culturable waste land, net area sown, total cropped area and area sown more than once. The increase in area under agricultural use may be attributed to various initiatives such as mission double cropping, bringing green revolution in Eastern India, RKVY etc. However, increase in area under non-Agricultural uses was due to sharp increase in population of the state. A substantial area from forest area has been put to non-agricultural uses causing negative growth in forest area for the entire study period. Further, it was observed that there has been higher concentration for land under misc. trees, groves, barren and unculturable land and land put to non-agricultural uses in Assam for the year of 2014-15. Care should be taken so that aforestation programme is undertaken to replenish deforestation. The cropping intensity has been steadily increasing over time in the state. Moderate level of crop diversification was observed in the state, which however had been declining in four major zones of Assam. More high value crops should be incorporated in the cropping system that would expect to increase both the farm income and cropping intensity.

\section{ACKNOWLEDGMENTS}

The paper is a part of the research carried out under ICAR-NIAP funded network project "Regional crop planning for improving resource use efficiency and sustainability." The research was supported by ICAR-National Institute of Agricultural Economics and Policy Research (NIAP). The authors cordially acknowledge Dr. Rajni Jain and her team for facilitating and providing insight and expertise that greatly assisted the research.

\section{REFERENCES}

Bhattacharyya, R. 2008. Crop diversification: a search for an alternative income of the farmers in the state of West Bengal in India, International Conference on Applied Economics, Kastoria, Greece, pp. 83-94.

Department of Agriculture, Ministry of Agriculture, Government of Assam

Directorate of Economics and Statistics, Government of Assam

Economics Survey, Various issues, Government of Assam

Rice Knowledge Management Portal, Indian Institute of Rice Research, ICAR, New Delhi http://www.rkmp.co.in

Lekhi, R.K. and Sigh, J. 2011. Agricultural Economics an Indian Perspective. New Delhi: Kalyani Publishers.

Premakumar and Seema. 2013. Land Use Pattern in India and Karnataka: A Comparative Analysis, International Journal of Scientific Research, 2(10): 2277 - 8179.

Mohanty, S. 2007. Population Growth and Changes in Land Use in India. Mumbai: IIPS Mumbai, ENVIS Centre. 
